\title{
Agglomeration Effects in Foreign Direct Investment and the Pollution Haven Hypothesis
}

\author{
Ulrich J. Wagner* \\ Department of Economics \\ Universidad Carlos III de Madrid
}

\author{
Christopher D. Timmins \\ Department of Economics \\ Duke University
}

August 29, 2008

\begin{abstract}
Does environmental regulation impair international competitiveness of pollutionintensive industries to the extent that they relocate to countries with less stringent regulation, turning those countries into "pollution havens"? We test this hypothesis using panel data on outward foreign direct investment (FDI) flows of various industries in the German manufacturing sector and account for several econometric issues that have been ignored in previous studies. Most importantly, we demonstrate that externalities associated with FDI agglomeration can bias estimates away from finding a pollution haven effect if omitted from the analysis. We include the stock of inward FDI as a proxy for agglomeration and employ a GMM estimator to control for endogenous, time-varying determinants of FDI flows. Furthermore, we propose a difference estimator based on the least polluting industry to break the possible correlation between environmental regulatory stringency and unobservable attributes of FDI recipients in the cross-section. When accounting for these issues we find robust evidence of a pollution haven effect for the chemical industry.
\end{abstract}

Keywords: agglomeration effects, congestion effects, environmental regulation, foreign direct investment, German manufacturing, panel data, pollution havens

JEL classification: F18, F23, Q52

${ }^{*}$ Correspondence to the first author at: Department of Economics, Universidad Carlos III de Madrid, Calle Madrid 126, 28903 Getafe (Madrid), Spain. E-mail: uwagner@eco.uc3m.es. This is a substantially revised version of an earlier draft dated March 2004 for which we gathered additional data to almost double country coverage. We would like to thank Manuel Arellano, Mike Boozer, Philipp Schmidt-Dengler, Peter Schott and participants at the 2003 NBER Summer Institute in Public Policy and Environmental Economics, at the Kiel Institute for World Economics staff seminar, and at the Yale Environmental Economics seminar for insightful comments. We thank Andrea Tschaban and Bernd Herbinger at Deutsche Bundesbank for making the FDI data available to us. The usual disclaimer applies. 


\section{Environmental Regulation and Pollution Havens}

Does environmental regulation impair international competitiveness of pollution-intensive industries to the extent that they relocate to countries with less stringent environmental regulations, turning those countries into "pollution havens"? This question has been the matter of a vigorous and controversial policy debate for years, and it continues to be of central interest to policy makers, public sector economists, and the general public. Recently, the issue has received attention in the context of assessing the environmental impacts of international trade agreements such as NAFTA and the WTO, and in broader debates about "globalization". It also plays an important role in the design of international environmental agreements such as the Montreal Protocol on ozone depleting substances and the Kyoto Protocol on greenhouse gas control. The effectiveness and stability of such agreements crucially depend on whether dirty production technologies are effectively banned or simply relocate to non-member countries 1

While the economic rationale behind the pollution haven effect has been well established in theoretical research, the empirical evidence on whether it matters in the real world is not conclusive as of yet. Empirical researchers have attributed this negative finding in part to difficulties with finding exogenous measures of regulatory stringency and to particular forms of unobserved heterogeneity, such as a lack of geographic mobility or high capital intensity of polluting industries.

This paper examines whether the omission of externalities from industrial agglomeration can account for the lack of evidence for the pollution haven hypothesis in previous work. Agglomeration externalities are a key ingredient of economic theories of cities, of the new trade theory, and of economic geography. However, notwithstanding a large body of empirical

\footnotetext{
${ }^{1}$ See Wagner (2001) for a survey article on environmental treaty formation and the pollution leakage problem. The book by Scott Barrett (2003) is an exhaustive source of information on the subject of international environmental agreements.
} 
work that documents the importance of agglomeration effects for industrial location choice, the environmental economics literature has, by and large, ignored the implications of this finding for the study of pollution havens.

We use longitudinal data on outward FDI flows of German manufacturing industries in 163 destination countries to test the pollution haven hypothesis conditional on industrial agglomeration - proxied by cumulative FDI - in the destination country. To this end, we develop a two-step estimator that explicitly accounts for the endogeneity of cumulative FDI and other country characteristics. Our method controls for unobserved heterogeneity at the country level and flexibly accommodates dynamic specifications of investment demand. Furthermore, our use of a survey measure of the stringency of environmental regulation is novel to the literature, as most existing research relies on measures of pollution abatement cost that may be endogenous to plant location decisions. We find that ignoring agglomeration externalities masks the pollution haven effect in the chemical industry.

The paper is structured as follows. The next section reviews the literature on FDI and environmental regulation. Section 3 describes the econometric framework, and section 4 summarizes our data, along with explaining why Germany is a relevant country for such an analysis. In section 5 we report and discuss our results. Section 6 concludes.

\section{Related Literature}

Economists have tackled the issue of pollution havens in different ways.2 The common denominator across the various strands of research is that compliance with environmental regulation raises firms' costs. From there, the literature follows different avenues. Since pollution havens are manifest in the geographic concentration of plants producing pollution-intensive goods, they can in principle be detected by looking at either patterns of international trade

\footnotetext{
${ }^{2}$ For a recent survey see Brunnermeier and Levinson (2004).
} 
in dirty goods or at location decisions of multinational firms in pollution-intensive industries. Ideally, one would like to analyze changes in these patterns in response to the implementation of environmental regulation.

Many researchers have analyzed this problem by looking directly at trade flows.3 More relevant for our study is a strand of the literature that focuses on the role of capital mobility. This line of research is based on the assumption that capital used in the production of pollution-intensive goods yields a higher marginal product in countries where firms do not bear the cost of compliance with environmental standards. As some countries impose such standards and others do not, capital should move internationally to equalize rates of return. The economic vehicle for this arbitrage mechanism is foreign direct investment by which firms in dirty industries relocate assets to countries with lax environmental regulations. These countries become pollution havens.

Most research in this area has focused on the relationship between environmental regulation in U.S. jurisdictions (i.e., states or counties) and the plant location decisions of international or domestic firms across those jurisdictions. This literature is comprehensively reviewed by Jeppesen et al. (2002). The studies cited in that survey attempt to explain the variation in the probability and/or the Poisson arrival rate of new manufacturing plant location decisions across jurisdictions by differences in environmental stringency measures and other characteristics of the chosen location. The results support a weak pollution haven effect at best; in most regressions, the environmental stringency measure is insignificant. Millimet and List (2004) suggest that this finding may be due to heterogenous responses to environmental regulation and corroborate their hypothesis with evidence from a propensity score matching estimator. A slightly different approach is taken by Keller and Levinson (2002) and List and Co (2000) who relate the total inward stock of FDI in U.S. states to

\footnotetext{
${ }^{3}$ For reviews of this literature, see e.g. Copeland and Taylor (2004), Grether and de Melo (2004), Jaffe et al. (1995), Scholz and Stähler (1999).
} 
measures of pollution abatement cost and other state characteristics, finding small but statistically significant deterrent effects of pollution abatement costs. Moreover these authors demonstrate that failure to account for unobserved heterogeneity in state characteristics can lead to an understatement of the pollution haven effect.

Studies of domestic pollution havens are relevant for public policy in the U.S. because they measure how multinational investors respond to environmental regulation conditional on their decision to open a plant in the U.S.. However, they cannot answer the politically explosive question of whether dirty industries relocate from industrialized to developing countries.

So far, only a few papers have used FDI data to study pollution havens at the global level. Smarzynska Javorcik and Wei (2004) study the determinants of actual and planned investment by 534 major multinational firms in Central and Eastern Europe and in the former Soviet Union. They find some evidence that more pollution-intensive firms are less likely to locate in more regulated countries, but the finding is not robust across specifications. Moreover, the effect vanishes when pollution intensity is measured by pollution abatement cost.

The measurement of pollution intensity is a key issue in empirical work on pollution havens. Most researchers have used data on abatement expenditures for pollution abatement and on investment in pollution abatement equipment. In a recent paper, Levinson and Taylor (2008) point out that if the most pollution-intensive plants within an industry have already relocated at the time expenditure data are collected, pollution abatement expenditures in the remaining plants are likely to be less than the industry average. This effect can bias the coefficient on pollution abatement cost in an investment or net export equation away from showing a pollution haven effect. The absence of a pollution haven effect in Smarzynska Javorcik and Wei (2004) may be a consequence of such bias.4

\footnotetext{
${ }^{4}$ An additional source of bias in their analysis may arise from unobserved heterogeneity in the cluster.
} 
In a case study of four developing countries, Eskeland and Harrison (2003) relate the sectoral composition of inward FDI in the host country to a measure of pollution intensity and control variables in two major source countries. All else equal, a high share of pollutionintensive industries in total FDI stock would lend support to the pollution haven hypothesis. Using either pollution abatement cost or normalized actual emissions per sector to proxy for pollution intensity, these authors find no evidence of a pollution haven effect after controlling for unobserved heterogeneity.

In a similar fashion, some authors exploit the variation in outward investment flows and in the stringency of domestic regulation across sectors to examine the importance of the pollution haven effect. For instance, Hanna (2004) studies the effect of the Clean Air Act Amendments (CAAA) on outbound FDI stocks using a panel data set of U.S. based multinational firms. She finds that overall investment by more regulated firms increased in response to the enforcement of CAAA regulations but she does not find a statistically significant effect on the share of FDI that those firms were holding in developing countries. In regressions explaining U.S. outward investment across industrial sectors, Eskeland and Harrison (2003) obtain negative or insignificant coefficients on pollution abatement cost. By contrast, when limiting the set of destination countries to Brazil and Mexico and controlling for capital intensity, Cole and Elliot (2005) find evidence that U.S. outward FDI flows across industries in the manufacturing sector vary positively with pollution abatement cost. Using a similar research design, Elliot and Shimamoto (2008) find a generally insignificant effect of pollution abatement cost on Japanese FDI flows to Indonesia, Malaysia and the Philippines.

While this approach sheds light on the link between environmental regulation and outsourcing of regulated industries in the source country, it does not control for regulatory stringency in the FDI host countries. This is important because the bulk of FDI in globalized industries (such as the chemical industry) flows between industrialized countries with equally strict environmental standards. Xing and Kolstad (2002) address this problem. They 
model industry-level FDI flows from U.S. manufacturing into a small cross-section of destination countries as a function of "environmental laxity" and other country characteristics. Since internationally comparable measures of environmental laxity are hard to obtain, they use sulfur dioxide $\left(\mathrm{SO}_{2}\right)$ emissions and other variables as proxies in the investment equation. They obtain positive and significant coefficients on $\mathrm{SO}_{2}$ emissions for the chemical and primary metals industries and interpret this as evidence for the pollution haven effect. In contrast, Kirkpatrick and Shimamoto (2007) find that a host country's membership in five global environmental agreements increases the probability of receiving Japanese foreign direct investment.

In concluding this literature review, we offer two observations that motivate much of the analysis in the remainder of the paper. First, using measures of environmental performance instead of regulatory stringency requires strong identifying assumptions on the underlying relationship between regulation and performance. For example, Xing and Kolstad s finding of a pollution haven effect hinges on the assumption that the latent relationship between unobserved environmental laxity and $\mathrm{SO}_{2}$ emissions is strictly increasing. As mentioned earlier, the use of pollution abatement cost as a measure of regulatory stringency rests on the assumption that compliance cost is exogenous to the process of relocation.

Our second observation is that the empirical literature on pollution havens has largely neglected to control for agglomeration externalities, a theoretical concept to explain location choice that has been shown to be important in numerous empirical studies $5^{5}$ On the one hand, industrial agglomeration engenders positive externalities by facilitating knowledge spillovers, upgrading the skill set of the labor force, and multiplying forward and backward linkages

\footnotetext{
${ }^{5}$ The idea of agglomeration and congestion externalities goes back to Marshall (1898) and has been further developed within the context of urban economics and international economics literatures, see e.g. Goldstein and Gronberg (1984), David and Rosenbloom (1990), Glaeser (1999), Krugman (1991). Wheeler and Mody (1992), Head et al. (1995), Head and Mayer (2004), Hilber and Voicu (2006) and others show that agglomeration effects matter empirically (see the latter paper for an up-to-date survey of this literature). Recently, Zeng and Zhao (2006) have developed a theoretical model of agglomeration effects in the context of environmental regulation.
} 
between industries. On the other hand, negative externalities may arise as firms bid up prices in local input markets and compete with one another as suppliers to downstream industries in the region. If agglomeration and/or congestion effects matter for an industry but are omitted from the estimation equation, this will cause bias in the estimated coefficient on environmental regulatory stringency. For instance, the positive coefficient on sulfur dioxide emissions in Xing and Kolstad (2002) could be explained in part by the fact that it proxies for agglomeration economies in dirty industries ${ }^{6}$

The reader should note that controlling for agglomeration effects in the investment equation is important even if a perfectly accurate measure of environmental regulatory stringency is available. If environmental regulatory agencies across countries respond to agglomeration of dirty industries by tightening environmental standards the resulting positive correlation between stringency and (omitted) agglomeration biases the results away from a pollution haven effect in an OLS regression. Bias may also arise if, as Cole et al. (2006) argue, foreign firms successfully lobby for lower environmental standards. However, the inclusion of measures of agglomeration in the investment equation poses econometric challenges because they are endogenous to the process of capital accumulation. In the remainder of the paper we propose a method that recovers a consistent estimate of the effect of environmental stringency on FDI flows in the presence of agglomeration externalities.

To summarize, the main points on which this paper builds are the measurement of environmental stringency, the role of agglomeration or congestion externalities and unobserved heterogeneity, and the time- and country-coverage of the FDI data. We first discuss our econometric methodology before we turn to the data and discuss the results.

\footnotetext{
${ }^{6}$ The bias will be smaller for clean industries since pollution emissions are not as good a proxy for agglomeration of clean industries than of pollution-intensive industries. The bias is alleviated to the extent that the instrumental variables these authors use for $\mathrm{SO}_{2}$ are uncorrelated with industrial agglomeration.
} 


\section{Econometric Model}

We start with the conjecture that FDI flows are determined by characteristics of the destination country that affect the profitability of the investment. Hence for each industry $i$, we can write FDI flows into country $j$ in year $t$ as:

$$
F D I_{i, j, t}=x_{j, t}^{\prime} \beta_{i}+z_{j}^{\prime} \gamma_{i}+a_{t}^{\prime} \theta_{i}+\mu_{i, j}+\eta_{i, j, t}
$$

where $x_{j, t}$ is a vector of time-varying attributes of country $j, z_{j}$ is a vector of time-constant attributes of country $j, a_{t}$ is a vector of year dummies, $\mu_{i, j}$ is a time-constant unobserved effect of country $j$ that is specific to industry $i$, and $\eta_{i, j, t}$ is an idiosyncratic disturbance that varies with time, country, and industry.

Consistent estimation of this equation involves addressing several econometric issues that we shall illustrate using the example of FDI agglomeration. A readily available measure of FDI agglomeration is the total stock of accumulated FDI $]^{7}$ given by the weighted sum of current and past FDI flows across sectors from Germany, $F D I(\cdot)$, and from all other countries, $\Phi_{i, j, t}(\cdot)$ :

$$
s_{j, t}=\sum_{\tau=0}^{\infty} \sum_{i} \kappa_{i, \tau}\left[F D I_{i, j, t-\tau}\left(\mu_{i, j}\right)+\Phi_{i, j, t-\tau}\left(\mu_{i, j}\right)\right]
$$

where $\kappa_{i, \tau}$ is a set of weights that account for depreciation. It follows that $s_{j, t}$ is a function of the unobserved country effect $\mu_{i, j}$ and - since the available measures of $s_{j, t}$ also contain current $F D I_{i, j, t}$ - it is also a function of all contemporaneous and past disturbances $\eta_{i, j, t}, \ldots, \eta_{i, j, 1}$. While the former causes omitted variable bias in OLS estimates of equation (1), the latter precludes application of panel data estimators that rely on the assumption

${ }^{7}$ Wheeler and Mody (1992) and others have used cumulative FDI as a proxy variable for agglomeration effects in FDI regressions. We discuss this measure in more detail in section 4 below. 
of strictly exogenous regressors $E\left(\eta_{i, j, t} \mid x_{j, 1}, \ldots, x_{j, T}, a_{1}, \ldots, a_{T}, z_{j}, \mu_{i, j}\right)=0 \forall t=0,1, \ldots, T$. As a consequence, we cannot employ fixed effects, random effects or the panel IV estimator suggested by Hausman and Taylor (1981) to deal with unobserved heterogeneity. $]^{8}$

A further shortcoming of conventional panel estimators is that they cannot accommodate dynamic specifications of foreign direct investment. In contrast, modern treatments of investment demand pay a great deal of attention to dynamics. For example, the well-known partial adjustment model of investment demand - a model that solves for the optimal investment path towards a target capital stock in the presence of a quadratic adjustment cost - yields the dynamic investment equation 9

$$
F D I_{i, j, t}=\alpha_{i} F D I_{i, j, t-1}+x_{j, t}^{\prime} \beta_{i}+z_{j}^{\prime} \gamma_{i}+a_{t}^{\prime} \theta_{i}+\mu_{i, j}+\eta_{i, j, t}
$$

We propose a two-stage algorithm ${ }^{10}$ to obtain consistent estimates of the parameters $\alpha$, $\beta, \gamma$, and $\theta$. In the first stage, we take first differences of equation (3) to eliminate the unobserved effect and estimate the equation

$$
\Delta F D I_{i, j, t}=\alpha_{i} \Delta F D I_{i, j, t-1}+\Delta x_{j, t}^{\prime} \beta_{i}+\Delta a_{t}^{\prime} \theta_{i}+\Delta \eta_{i, j, t}
$$

using the GMM estimator proposed by Arellano and Bond (1991). The estimator takes into account the correlation of the error term with the lagged dependent variable, $\operatorname{Cov}\left(\Delta F D I_{i, j, t-1}\right.$, $\left.\Delta \eta_{i, j, t}\right)<0$, and uses lagged levels $F D I_{i, j, t-2}, \ldots, F D I_{i, j, 1}$ to instrument for $\Delta F D I_{i, j, t-1}$. Sim-

\footnotetext{
${ }^{8}$ Notice that excluding current FDI flows would still preclude the use of those estimators because $s_{j, t}$ depends on all past disturbances $\eta_{i, j, t-1}, \ldots, \eta_{i, j, 1}$. This correlation cannot be broken by dropping German FDI from equation (2) either, because the presence of agglomeration/congestion effects means that nonGerman FDI flows may depend on cumulative German FDI flows in the same way in which we allow German FDI to depend on cumulative non-German FDI. We thank a referee for suggesting that we address this point explicitly.

${ }^{9}$ This equation is obtained after performing Koyck's transformation on an investment equation with geometrically distributed lags. Jorgenson (1966) generalizes this argument to rational lag distributions.

${ }^{10}$ See Bryk and Raudenbush (1992) for a discussion of multi-level modeling.
} 
ilarly, the endogenous variables such as the stock of FDI are instrumented for with lagged levels of order 2 or higher. Predetermined variables - i.e., explanatory variables that may respond to past inflows of FDI such as GDP - are instrumented using first and higher-order lags of the variable in levels.

Compared to the fixed effects estimator the benefits of the GMM estimator are twofold: First, it permits us to explore dynamic specifications of the investment equation which may be better suited to capture the year-to-year variation in investment flows. Second, it provides a way of instrumenting for explanatory variables that we suspect to be endogenous or predetermined.11 It bears noting that the estimator can also be applied to the static investment equation (1).

In the second stage, we compute the time-constant component of investment of industry $i$ in country $j$ as

$$
\hat{\delta}_{i, j} \equiv \frac{1}{T} \sum_{t=1}^{T}\left(F D I_{i, j, t}-\hat{\alpha}_{i} F D I_{i, j, t-1}-x_{j, t}^{\prime} \hat{\beta}_{i}-a_{t}^{\prime} \hat{\theta}_{i}\right)
$$

and regress it on observable country characteristics

$$
\hat{\delta}_{i, j}=\psi_{i}+z_{j}^{\prime} \gamma_{i}+\mu_{i, j}+\tilde{\eta}_{i, j}
$$

where the mean of the fitted residuals $\hat{\eta}_{i, j, t}$ has been decomposed into a constant $\psi_{i}$ and the deviations $\tilde{\eta}_{i, j} \equiv \overline{\hat{\eta}_{i, j, t}}-\psi_{i}{ }^{12}$ Denote by $\tilde{\mu}_{i, j} \equiv \mu_{i, j}+\tilde{\eta}_{i, j}$ the composite error term of the second-stage regression.

\footnotetext{
${ }^{11}$ Anecdotal evidence for this sort of endogeneity is the "Celtic Tiger" boom of the Irish economy, which was allegedly facilitated by the Irish government aggressively lowering corporate income tax rates in order to attract high tech industries.

${ }^{12} \mathrm{As}$ an alternative to the two-step procedure suggested here, we could follow Arellano and Bover (1995) and include the orthogonality conditions used in the second stage along with the ones of the first stage into a system GMM estimator and estimate all parameters in a single step to obtain more efficient estimates. However, the convergence properties of this estimation procedure have proven to be poor in our relatively small sample.
} 
While the first-stage regression produces consistent coefficient estimates for all timevarying variables, the inference in the second stage is purely cross-sectional. Hence, if country specific unobservables $\tilde{\mu}_{i, j}$ are correlated with elements of $z_{j}$, OLS estimates of $\gamma_{i}$ will be biased. This is true, for example, when average FDI stock $\bar{s}_{j}\left(\mu_{i, j}\right)$ is included in the second stage. In the estimations below, we will include environmental regulatory stringency in the vector $z$ due to limited time series variation in the data. Since this is the variable of primary interest in this study, we propose the following procedure to obtain consistent estimates of stage-two coefficients. Decompose the error $\tilde{\mu}_{i, j}$ as follows:

$$
\tilde{\mu}_{i, j}=\omega_{j}+\nu_{i, j}
$$

where $\omega_{j}$ and $z_{j}$ are correlated in an arbitrary fashion and $\nu_{i, j}$ is orthogonal to $z_{j}$. That is, unobserved country heterogeneity does not vary systematically with $z_{j}$ across industries ${ }^{13}$ Under this assumption, difference estimators for any two industries are consistent even in the presence of unobserved heterogeneity in the cross-section. To see this, consider the stage-two estimation equations for two industries of differing pollution-intensity:

$$
\begin{aligned}
& \hat{\delta}_{d, j}=\psi_{d}+z_{j}^{\prime} \gamma_{d}+\omega_{j}+\nu_{d, j} \\
& \hat{\delta}_{c, j}=\psi_{c}+z_{j}^{\prime} \gamma_{c}+\omega_{j}+\nu_{c, j}
\end{aligned}
$$

where subscripts $d$ and $c$ indicate a "dirty" and a "clean" industry, respectively. We subtract the latter equation from the former so as to eliminate $\omega_{j}$ and obtain what we call the control-

\footnotetext{
${ }^{13}$ This assumption would clearly be violated in the case of a mineral extraction industry (e.g., oil), where mineral stocks would provide a strong advantage for the host country that is specific to that industry. We omit such industries from the analysis.
} 
industry difference equation

$$
\Delta^{d-c} \hat{\delta}_{j}=\Delta^{d-c} \psi+z_{j}^{\prime} \Delta^{d-c} \gamma+\Delta^{d-c} \nu_{j}
$$

We estimate this equation by OLS to obtain consistent estimates of the parameters. The pollution haven effect is identified under the additional assumption that clean industries are not attracted by more stringent environmental regulation, i.e. that $\gamma_{c}^{\text {stringency }} \leq 0$. If this is true, testing

$$
H_{0}: \Delta^{d-c} \gamma^{\text {stringency }}=0 \quad \text { versus } \quad H_{1}: \Delta^{d-c} \gamma^{\text {stringency }}<0
$$

enables us to verify if the sign of the effects estimated in the second-stage regression are robust to unobserved heterogeneity. If one is not willing to make that assumption, the estimates from the control-industry difference regressions can be interpreted as the relative deterrent effect of environmental regulation on dirty and clean industries.

\section{Data}

Germany is an attractive country for testing the pollution haven hypothesis for several reasons. For starters, the German economy is the largest in the European Union, located favorably in the center of the continent and connecting the Common European Market with the Central and Eastern European economies in transition, several of which have recently become member states of the European Union. German manufacturing is highly competitive and accounts for a large surplus in the economy's balance of trade while at the same time being subject to very strict environmental standards and rigorous enforcement. In the 2004 Executive Opinion Survey conducted by the World Economic Forum, business executives ranked Germany as the first among 102 countries in terms of the overall stringency of environmental regulation and enforcement (World Economic Forum et al., 2004). This suggests 
that, ceteris paribus, pollution-intensive industries in Germany face stronger incentives to go abroad than they do in most other countries in the world. Finally, the choice set of potential destination countries available to German firms is large and exhibits considerable heterogeneity in country attributes 14

This paper exploits two sources of data that have not been widely used in previous research on the issue of pollution havens. The first one is a panel data set on outward FDI flows by German manufacturing firms into different destination countries. There are three sources of variation in FDI flows: (i) annual variation between the years 1996 and 2003, (ii) cross-sectional variation across the 163 destination countries, and (iii) variation across 24 industries at the 2-digit level of the German WZ93 classification code. The analysis is performed on a subset of six industries that exhibit substantial variation in their degree of pollution intensity and for which we have a sufficient number of observations (up to 90 countries in the cross-section).

The second data source is our measure of environmental stringency (STRINGENCY). We use a variable taken from the above-mentioned Executive Opinion Survey (World Economic Forum et al., 2003) which measures the "overall stringency of environmental regulations and enforcement" on a scale from 1 to $7 \sqrt{15}$ This variable conveys a subjective assessment of regulatory stringency that we deem relevant for testing the pollution haven hypothesis. The reason is that the assessment of environmental regulatory stringency is provided by individuals who routinely assess and decide on investment options. The benefits of using this variable are twofold: First, it has been collected for more than a hundred destination

\footnotetext{
${ }^{14}$ For example, consider a firm based in Frankfurt (Main) that would like to open a plant no further than $500 \mathrm{~km}$ from its registered office. Potential location choices include sites in EU countries with equally (Denmark, Netherlands) or almost equally stringent (Belgium, France) environmental regulations as well as non-EU countries with similar environmental standards such as Switzerland and others like Poland and the Czech Republic where environmental regulation is significantly less stringent.

${ }^{15} \mathrm{We}$ are aware of only one other paper that has used this measure of environmental stringency. Kellenberg (2008) finds strong evidence of a pollution haven effect in U.S. outward multinational affiliate production, particularly for 'footloose' industries like electronics and appliance manufacturing.
} 
countries, thus offering broader country coverage than any of the variables used in previous research. Second, by relying on business executives' own perception of the stringency and enforcement of environmental regulation in a given country we are able to circumvent the problems with performance-based measures discussed above.16

We estimate the investment equation (1) by regressing total FDI flows on both timevariant and time-constant characteristics of the host countries. The choice of covariates is guided by the need to control for factors that affect the expected profitability of an investment in a given location (see Markusen, 1995, for a review). If foreign affiliates serve local markets, then large markets promise higher returns on investment ceteris paribus. We follow the empirical literature and include GDP as a proxy for market size (e.g. Brainard, 1997). Further, the profitability of FDI as a substitute for trade increases with the degree of tariff protection of the local market and with the cost of shipping goods from Germany. Therefore, we control for the level of tariff protection (TARIFF) and for distance from Germany $(\ln ($ DISTANCE)). In addition, we include the maximal corporate income tax rate (TAX) which may affect after-tax returns on FDI, and the exchange rate (EXRATE) which is inversely related to the cost (in $€$ ) of a given investment in local currency units.

Apart from market segmentation and financial factors, the profitability of an investment also depends on the quality of local factor inputs. We include the literacy rate (LITERACY) as a proxy for human capital and the total length of the paved road network $(\ln (\mathrm{ROADS}))$ as a proxy for transportation infrastructure (Cheng and Kwan, 2000). Since this variable might pick up a size effect, we also include the total area of a country (ln(AREA)) so as to control for road density. Finally, the quality of institutions affects both the cost of doing business and the risk premium that the parent companies demand on their investments (Wheeler and

${ }^{16}$ That is, neither do we need to assume a particular relationship between regulation and environmental performance, nor do we have to make the assumption that pollution abatement cost is exogenous to the process of relocation. An innovative approach to measuring environmental stringency is the shadow price indicator proposed by van Soest et al. (2006). Unfortunately, we cannot calculate their indicator since abatement cost data are not available for most of the countries in our sample. 
Mody, 1992). We thus include an index that measures the strength and impartiality of the legal system as well as popular observance of the law (LAW\&ORDER).

A key objective of our analysis is to control for the effect of agglomeration/congestion externalities on FDI flows. One way of doing this is by including the number of foreign affiliates in the host country (Head et al., 1995, Head and Mayer, 2004). In a firm-level analysis of German FDI using the Bundesbank's International Capital Links database, Buch et al. (2005) control for the number of German multinational firms located in a given host country. Since we do not have access to this data set, we follow Wheeler and Mody (1992) and Cheng and Kwan (2000) in using the total stock of inward FDI (FDISTOCK) as a proxy for agglomeration/congestion externalities $\sqrt{17}$ While a proxy for agglomeration that varies by industry might seem preferable, FDISTOCK offers the fundamental advantage that it is readily available for a large cross-section of countries.

Summary statistics of time-varying and time-invariant variables are displayed in tables 1 and 2, respectively. While area and distance are truly constant over time, the other variables in table 2 are actually time-varying but we do not have sufficient time-varying information in the given time window. The data appendix provides detailed information on data sources and units of measurement for all variables.

[Table 1 about here.]

[Table 2 about here.]

\footnotetext{
${ }^{17}$ Notice that Buch et al. (2005) measure agglomeration effects between German firms only, whereas we are interested in controlling for externalities from industrial agglomeration regardless of the source country.
} 


\section{$5 \quad$ Estimation and Results}

\subsection{Econometric Specification}

Our estimation procedure will include most time-varying variables in the first stage and all time-constant variables in the second stage. We look to the summary statistics for guidance on the adequate treatment of FDI (both stocks and flows) and regulatory stringency in the estimation.

Table 1 shows that FDI flows assume both positive and negative values and exhibit a high year-to-year variability. This leads us to explore the explanatory power of lagged investment for all industries. Notice that more than half of the variation in the investment series is within countries, i.e. first differencing leaves a substantial amount of variation to be explained in the first-stage regression.

Technically, STRINGENCY is a time-varying variable that could be included in the first-stage regression. While this identification strategy offers a direct way of controlling for both unobserved heterogeneity and potential endogeneity, it also has some drawbacks. First, country coverage for this variable falls short of that in the FDI data, especially at the beginning of the panel ${ }^{18}$ Second, since $95 \%$ of the variance in STRINGENCY is due to cross-sectional heterogeneity the GMM estimator throws away most of the variation in this variable and relies instead on year-to-year changes to identify its effect on FDI. This begs the question whether such changes correspond to actual changes in environmental regulation or simply reflect changes in the interview process and/or the composition of respondents. In order to address such concerns we include STRINGENCY as a time-constant variable in the second stage of our control-industry difference estimator.

Table 2 also shows that most of the variation in FDISTOCK is between countries. Hence,

\footnotetext{
${ }^{18}$ The World Economic Forum began to incorporate questions about environmental regulation in the Executive Opinion Survey in 2000 and has since been expanding the country coverage.
} 
if FDISTOCK were included in the first-stage regression, most of the information in this variable would be discarded as the GMM estimator relies only on year-to-year changes for identification. While the level of FDISTOCK is a reasonable proxy for industrial agglomeration in the host country, the annual change in FDISTOCK is unlikely to pick up agglomeration economies or congestion effects. This is because agglomeration externalities depend on the skill composition of the labor force, knowledge flows, market structure, and other country characteristics that evolve over the long term and tend to be constant over the relatively short estimation period considered here. In view of these concerns, we include both STRINGENCY and FDISTOCK in the second-stage regression.19

First-stage regression Estimation proceeds as described in section 3, In the first stage, we estimate eq. (4) by $\mathrm{GMM}^{20}$ using twice-lagged levels to instrument for explanatory variables that are endogenous. Apart from the lagged dependent variable, we treat TAX and EXRATE as endogenous because governments may set taxes so as to attract foreign investors, and because exchange rates are likely to respond to large changes in FDI. GDP and TARIFF are assumed to be predetermined as those variables may respond to past inflows of FDI that develop productive effects and may affect trade policy. The estimation period is 2001 through 2003, and some observations from previous years are used to generate the instruments. The choice of this estimation period ensures that the estimated country-byindustry effects $\delta_{i, j}$ correspond to the 2003 values of STRINGENCY that we use in order to maximize country coverage in the second stage. ${ }^{21}$ This step provides us with consistent

\footnotetext{
${ }^{19}$ When the investment equation is estimated with time-varying STRINGENCY and FDISTOCK in the first stage, the coefficient on STRINGENCY is not significant at conventional levels for any industry. This corroborates our conjecture that taking first differences compounds measurement error in the STRINGENCY variable. The results are available upon request.

${ }^{20}$ All panel GMM models were estimated in STATA using the xtabond2 command by David Roodman, available online at http://econpapers.repec.org/software/bocbocode/s435901.htm.

${ }^{21} \mathrm{~A}$ referee raised concerns about reverse causality if an increase in foreign direct investment increases income and hence the demand for environmental quality. We think that this effect is plausible in the longrun but presumably rather small during our three-year period of analysis. If reverse causality is relevant, note that it would bias our results away from finding a pollution haven effect by generating a positive correlation
} 
estimates of $\alpha_{i}, \beta_{i}$ and $\theta_{i}$ that we use to calculate $\hat{\delta}_{i, j}$ in equation (5).

Control-industry difference regression The second-stage equation (6) is a linear regression of $\hat{\delta}_{i, j}$ on STRINGENCY, average FDISTOCK ${ }^{22}$ LITERACY, LAW\&ORDER, $\ln (\mathrm{ROADS}), \ln (\mathrm{AREA}), \ln (\mathrm{DISTANCE})$, and a constant term. In order to implement the control-industry difference equation (10) we need to identify a comparatively "clean" control industry. We follow the common practice in the literature and use pollution abatement expenditures to classify industries according to their pollution intensity.

[Figure 1 about here.]

Figure 1 depicts the evolution of the share of abatement investment in total investment over time for the six industries we study and for total manufacturing, based on data from the German Federal Statistical Office (Bundesamt für Statistik). The figure shows that the share of abatement investment was declining between 1996 and 2003 in most industries ${ }^{23}$ However, the relative ranking across industries is preserved over time and hence appears to be an appropriate basis for classifying industries as "dirty" or "clean" ${ }^{24}$ Since the least pollution-intensive industry in our sample is electrical equipment we use this industry to control for unobserved heterogeneity in the cross-section when estimating equation (10). In particular, we regress the difference between the $\hat{\delta}_{i, j}$ for industry $i$ and for electrical equipment on time-invariant country characteristics to obtain an unbiased estimate of the differential effect of STRINGENCY on FDI.

between FDI inflows and environmental regulatory stringency in the host country.

${ }^{22}$ To get a time-invariant measure of FDISTOCK that does not contain the dependent variable, we subtract total FDI by German manufacturing from FDISTOCK and average the remainder over the years 2001 to 2003.

${ }^{23}$ This observation is consistent with the conjecture that pollution abatement cost is endogenous to the relocation of dirty plants (Levinson and Taylor, 2008) and provides further justification for not using cardinal information in this variable to identify the pollution haven effect.

${ }^{24} \mathrm{~A}$ ranking based on data on current abatement expenditures is consistent with this ranking. 


\section{$5.2 \quad$ Results}

Table 3 reports coefficient estimates and robust standard errors for the first-stage equation (4). All specifications include year dummies to control for economy-wide shocks to outward FDI. We report the results from a dynamic investment equation only if the coefficient on the lagged dependent variable is statistically significant at $10 \%$ or better, which is true in the automobile and electrical equipment industries. ${ }^{25}$ There is no evidence of second-order autocorrelation in the residuals and a Sargan test of overidentifying restrictions cannot reject the instruments at $5 \% 26$

[Table 3 about here.]

The estimated coefficients on lagged FDI are negative, reflecting the lumpiness of FDI flows. We also find a significant positive coefficient on GDP in most industries, confirming the notion that firms locate in close proximity to large markets. Since the estimated relationship is a reduced form of the short-run equilibrium allocation of FDI, this estimate may also be picking up effects associated with high GDP that reduce profits such as higher wages in the manufacturing sector. This would explain why the coefficient is negative for the chemical industry and insignificant for primary metals and electrical equipment.

The insignificant estimates of the TAX coefficient speak to the lack of empirical evidence that tax avoidance is an important motive for FDI ${ }^{27}$ A possible explanation for the posi-

\footnotetext{
${ }^{25}$ When we estimated dynamic investment equations for all industries, the lag coefficients were not significant at $10 \%$ for the primary metals, chemical, paper, and machinery industries. Moreover, a Sargan test of overidentifying restrictions rejected the instruments at the $5 \%$ level for both the chemical and the paper industries. The results are available upon request.

${ }^{26}$ While first-order autocorrelation in the differenced residuals is an artifact of the procedure, second-order serial correlation invalidates the instrumenting strategy. We report the $z$ statistic of the Arellano and Bond test for second-order serial correlation in the error terms. The statistic is normally distributed under the null of no serial correlation. We also include Sargan's statistic and the marginal $p$ value associated with rejecting the overidentifying restrictions.

${ }^{27}$ As Markusen (1995, p. 171) puts it: "Apparently, most firms choose foreign production locations, and then instruct their tax departments to minimize taxes.
} 
tive tax coefficient for the automobile industry is that taxes are positively correlated with government spending on highways and transport infrastructure that benefits this industry more than others. The coefficient on the exchange rate has the expected negative sign for five of the six industries but it is not statistically significant. This suggests that most of the variability in the external value of the Euro is collinear across countries and thus captured by the year dummies. The coefficient on TARIFF could not be precisely estimated either. While high tariffs should render investment into local production facilities more attractive as a substitute for trade, they might be correlated with unobserved factors that deter FDI. Since we lack adequate data to separately control for such opposing effects, they may result in coefficient estimates not significantly different from zero ${ }^{28}$ A Wald test of joint significance indicates that the coefficient estimates are jointly significant at $5 \%$ percent or better for all industries except primary metals (19\%). Therefore, the first-stage regression coefficients can be used to compute $\hat{\delta}_{i, j}$ as the annual average flow of FDI in industry $i$ to country $j$ net of the influence of time-varying attributes of country $j$.

Table 4 shows the estimated coefficients of the second-stage equation (6). For each industry, we first estimate a univariate regression with STRINGENCY only. We then add average FDISTOCK and other controls. Robust standard errors are reported in order to account for arbitrary forms of heteroskedasticity and spatial correlation.

[Table 4 about here.]

The most salient result is that the coefficient on FDISTOCK is statistically significant for each of the six industries and explains a great deal of the variation in $\hat{\delta}_{i, j}$. The coefficient measures the net effect of agglomeration economies and congestion effects in a given industry. We find that agglomeration economies dominate in the chemical and electric equipment

\footnotetext{
${ }^{28}$ Another explanation is measurement error, as tax rates may vary according to firm circumstances and tariffs do not necessarily vary in lock-step with unobserved non-tariff barriers to trade.
} 
industries whereas congestion externalities prevail in all other industries. Pairwise comparison of the first and second columns for each industry shows the extent of the bias that arises from omitting FDISTOCK. Consider, for example, the automobile industry in panel D. When FDISTOCK is omitted from the regression it seems as if STRINGENCY had a negative and statistically significant effect on FDI (column 6). However, once FDISTOCK is controlled for the coefficient loses statistical significance (column 7) and eventually becomes insignificant as more controls are included (columns 8-10). This suggests that STRINGENCY picks up the negative effect of FDISTOCK when this variable is omitted. A similar yet less pronounced pattern arises for machinery in panel E. Conversely, for the electrical equipment industry in panel $\mathrm{F}$ the coefficient on STRINGENCY changes from positive and significant to around 0 and insignificant as FDISTOCK enters the regression with a positive and statistically significant coefficient estimate. Again, the STRINGENCY coefficient is severely biased due to the omission of FDISTOCK.

While the direction of the bias varies across industries, there is a clear pattern that the omission of FDISTOCK causes systematic bias in the coefficient estimates for STRINGENCY. The results for the chemical industry in panel B demonstrate that this bias masks the pollution haven effect. The univariate regression in column 6 gives a positive yet insignificant coefficient on stringency. FDISTOCK enters the regression with a positive and significant coefficient in column 7 and the STRINGENCY coefficient becomes negative and statistically significant. As additional controls variables are added in columns 8 through 10, coefficient estimates for both variables shrink somewhat in magnitude but remain statistically significant.

As is the case with STRINGENCY, the importance of the other control variables varies across industries. We find a deterrent effect of LITERACY for the chemical and paper industries. LAW\&ORDER is positively associated with FDI in the primary metals industry. The proxy for transport infrastructure, $\ln (\mathrm{ROADS})$ has a negative coefficient for the primary 
metals, paper, and automobile industries and a positive one for the chemical industry. However, this coefficient becomes insignificant when $\ln (\mathrm{AREA})$ is included except in the case of paper. No systematic effect is found for $\ln (\mathrm{DISTANCE})$.

Even when FDISTOCK and other country characteristics are included in the regression it is possible that unobserved heterogeneity causes bias in the coefficient estimates. As explained above, our control-industry difference estimator purges the estimates of bias caused by country-specific unobserved effects that are common across industries. Table 5 reports the STRINGENCY coefficient obtained when electrical equipment is used as the control industry in the difference equation (10). If we assume that electrical equipment is not attracted by environmental regulatory stringency, a negative coefficient can be interpreted as evidence of the pollution haven effect 29

[Table 5 about here.]

For each industry, we report the estimated STRINGENCY coefficients from a univariate regression and from a regression that includes the set of control variables that we found to be statistically significant in table 4. The table shows that STRINGENCY is negative and statistically significant in univariate regressions for the chemical and automobile industries at $5 \%$ and for machinery at $10 \%$. Upon including the other control variables, we find statistically significant evidence of a pollution haven effect for the chemical industry only ${ }^{30}$ The point estimate for the STRINGENCY coefficient is -101.693, about one fourth smaller in magnitude than the coefficient in the univariate regression 31

\footnotetext{
${ }^{29}$ This assumption remains essentially untestable. Incidentally, we note that we have not found evidence that would discredit this assumption. The coefficient estimates for STRINGENCY that we obtain in columns 7 through 10 of panel $\mathrm{F}$ in table 4 are close to zero, mostly negative, and statistically insignificant. When we included time-varying STRINGENCY in the first-stage regression for electrical equipment (see footnote 19 on page 18p we found a negative but statistically insignificant stringency coefficient.

${ }^{30}$ We have investigated non-linear effects of environmental regulation by including the square of STRINGENCY but did not find any statistically significant effects.

${ }^{31}$ In following a referee's suggestion, we repeated the analysis for the chemical industry using all 50 developing countries in our sample. This amounts to truncating the choice set for German investors at
} 
It is instructive to compare these estimates with those reported for the chemical industry in table 4. First, notice that the stringency coefficient in the univariate regression drops from 63.361 in the level equation (column 6 of panel B in table 4) to -131.561 in the difference equation (column 3 of table 5). This shows that differencing alone is very effective at reducing omitted variable bias. The reason for this is that FDISTOCK has a very similar effect on both the chemical and the electrical industries, most of which cancels out as an unobserved country effect $\omega_{j}$ in the difference equation. Second, upon including FDISTOCK and other controls ${ }^{32}$ the difference between the estimated STRINGENCY coefficients in equations (6) and (10) shrinks to less than $10 \%$. This suggests that the controls in the level equation in fact capture most of the heterogeneity in the cross-section. Overall, these findings provide robust evidence of a pollution haven effect for the chemical industry.

\subsection{Discussion}

Our findings demonstrate that in an empirical analysis of the relationship between environmental regulation and FDI flows, it is important to control for stock externalities associated with FDI accumulation because they can mask the pollution haven effect. The results for the chemical industry - the driving force behind the globalization of the German manufacturing sector - illustrate the importance of agglomeration externalities and omitted variable bias particularly well. Döhrn (2002) explains that FDI in the chemical industry has traditionally been concentrated in industrialized countries and this trend has grown even stronger over recent years. He also reports that, when interviewed about the determinants of FDI, managers of German multinational firms in the chemical industry stressed the importance of

the 85th percentile of the STRINGENCY distribution and reduces its variation by about one third. The coefficient estimate is negative, yet smaller in magnitude and not statistically significant at the $5 \%$ level.

${ }^{32}$ To the extent that those variables affect an industry in a different way than the control industry, it is important to include them in the control-industry regressions. We find that FDISTOCK is always statistically significant, $\ln (\mathrm{ROADS})$ is significant for the primary metals, paper (10\%) and automobile industries, LITERACY is significant for the chemical and paper (10\%) industries, and LAW\&ORDER is significant at $10 \%$ for the chemical industries. 
agglomeration benefits. These observations are consistent with our finding that (i) average FDISTOCK enters the FDI regression for this industry with a positive sign and that (ii) environmental stringency acts as a proxy for FDI agglomeration benefits when FDISTOCK is excluded, which results in the coefficient on stringency being biased away from the pollution haven effect.

After we control for both agglomeration externalities and unobserved heterogeneity we obtain statistically significant evidence of a pollution haven effect for the chemical industry, the second-most pollution-intensive industry in our sample. How important is this effect economically? Our point estimate of -101.693 implies that a country that reduced its regulatory stringency by one standard deviation (e.g. the difference between Austria and neighboring Slovakia) would gain on average $€ 122,032$ in foreign direct investment per year ${ }^{33}$ Since this corresponds to almost two thirds (0.66) of the standard deviation of annual investment flows in the chemical industry, we conclude that the deterrent effect of environmental regulatory stringency on FDI is economically significant.

Why is it that we do not find a similar effect for the other pollution-intensive industries - primary metals and paper? A possible explanation for this puzzle is that these industries are less geographically mobile than the chemical industry. For instance, Ederington et al. (2005) have shown that the effect of environmental regulatory stringency on commodity trade is more pronounced in geographically mobile industries. Primary input factors in the manufacture of basic metals include ore and energy. While Germany imports virtually all of its iron ore from overseas, energy has been cheap thanks to heavy subsidization of domestic coal mining for political reasons. In addition, other factors may impede the relocation of steel producers in spite of strict environmental regulations, such as the proximity to the domestic market and sizable agglomeration economies in the Rhine-Ruhr area where much

\footnotetext{
${ }^{33}$ This effect is relative to the effect of stringency on electrical equipment and thus represents a lower bound on the effect of stringency on FDI flows in the chemical industry.
} 
of the industry is traditionally located.

Our FDI data for the paper industry covers the production of both wood pulp and paper. These production processes have been largely decoupled in Europe, and they exhibit different degrees of pollution intensity and geographic mobility: While the production of pulp is a pollution-intensive process for which proximity to forests matters, paper production is less environmentally harmful and located closer to the consumer (Scholz and Stähler, 1999). Unfortunately, in our data we cannot distinguish between the relocation of a paper mill and the vertical integration of a pulp factory, although both is likely to be going on 34 Moreover, the pulp industry's dependence on timber resources may introduce an industry-specific unobserved effect that does not cancel out in the control-industry difference regression. Addressing these issues by collecting data on the location of resource deposits and more disaggregate FDI data is beyond the scope of this paper and left as a topic for future research.

\section{Conclusion}

Researchers studying the determinants of FDI have produced a substantial amount of increasingly sophisticated empirical work to explain the lack of strong evidence supporting the pollution haven hypothesis (in the environmental economics literature) and to document the importance of agglomeration externalities for industrial location choices and explain their precise workings (in the international and urban economics literatures). So far, these literatures have evolved in a parallel fashion and the implications of agglomeration/congestion effects have been ignored in tests of the pollution haven hypothesis. This paper is the first empirical study of the effect of environmental regulatory stringency on FDI to take the role of agglomeration externalities seriously.

\footnotetext{
${ }^{34}$ For instance, the largest investment in the data occurs in 2002 and goes to Finland, the leading European producer of wood pulp and second-largest exporter after Sweden. Both countries rank consistently among the top 6 countries with the most stringent environmental regulation and enforcement in the study period. The FAO (2007) reports that Germany is a large net importer of wood pulp for domestic paper production.
} 
We develop a two-step econometric procedure that controls for industrial agglomeration and unobserved heterogeneity when regressing FDI flows on environmental regulatory stringency and other country attributes. The first stage implements a GMM estimator for dynamic panel data (Arellano and Bond, 1991) which allows us to instrument for endogenous country characteristics and to control for serial correlation in FDI flows. The second stage uses the least pollution-intensive industry to control for time-constant unobserved heterogeneity in the cross-section.

We apply this method using two sources of data that have not previously been used in the literature on pollution havens. The first is a comprehensive panel data set on outward FDI flows from various two-digit industries in the German manufacturing sector that exhibit substantial dispersion in pollution intensity. The second is a survey measure of environmental regulatory stringency whose validity does not hinge on identification assumptions and that does not suffer from potential endogeneity as do stringency measures that are based on pollution abatement cost.

Our results underline the importance of controlling for agglomeration externalities, proxied by cumulative FDI, and demonstrate how omitting them from the analysis can mask the pollution haven effect. When properly accounting for those effects, we find statistically and economically significant evidence that more stringent environmental regulation deters FDI in the chemical industry. No such effect is found for two other pollution-intensive industries, primary metals and paper. We conjecture that this lack of an effect is owed in part to aggregation issues and to the lack of geographic mobility of some pollution-intensive industries documented by Ederington et al. (2005). What is more, for two out of six industries we find that a dynamic specification fits the data better than a static investment equation.

Future work may improve on this study in various ways. To begin, future improvements in the survey design regarding the intertemporal consistency and country coverage of the environmental regulatory stringency variable may render the control-industry difference ap- 
proach unnecessary. Moreover, as more disaggregate FDI data become available, it will be possible to control for the vertical integration of production processes with very different pollution intensities.

In the meantime, it should be instructive to carry out similar analyses for other FDI source countries to see if the pattern of relocation across industries is similar. The data could also serve as an additional source of variation for our difference estimator. Finally, in order to shed more light on the complex issue of agglomeration externalities and the pollution haven effect, it seems worthwhile to look for proxy variables that separately control for beneficial and detrimental effects of FDI agglomeration, instead of using a single proxy variable for both.

\section{References}

Arellano, M. and Bond, S.: 1991, Some tests of specification for panel data: Monte Carlo evidence and an application to employment equations, Review of Economic Studies 58, 277297.

Arellano, M. and Bover, O.: 1995, Another look at the instrumental variable estimation of error-components models, Journal of Econometrics 68(1), 29-51.

Barrett, S.: 2003, Environment $\&$ Statecraft, Oxford University Press, Cambridge, MA.

Brainard, S. L.: 1997, An empirical assessment of the proximity-concentration trade-off between multinational sales and trade, American Economic Review 87(4), 520-544.

Brunnermeier, S. and Levinson, A.: 2004, Examining the evidence on environmental regulations and industry location, Journal of Environment $\&$ Development 13(1), 6-41.

Bryk, A. S. and Raudenbush, S. W.: 1992, Hierarchical Linear Models: Applications and 
Data Analysis Methods, Vol. I of Advanved Qualitative Techniques in the Social Sciences, Sage Publications, Newbury Park,CA.

Buch, C., Kleinert, J., Lipponer, A. and Toubal, F.: 2005, Determinants and effects of foreign direct investment: evidence from German firm-level data, Economic Policy 41, 51-110.

Cheng, L. K. and Kwan, Y. K.: 2000, What are the determinants of the location of foreign direct investment? The Chinese experience, Journal of International Economics 51, 379400.

Cole, M. A., Elliot, R. J. and Fredriksson, P. G.: 2006, Endogenous pollution havens: Does FDI influence environmental regulations, Scandinavian Journal of Economics 108(1), 157178.

Cole, M. A. and Elliot, R. J. R.: 2005, FDI and the capital intensity of "dirty" sectors: A missing piece of the pollution haven puzzle, Review of Development Economics 9(4), 530548.

Copeland, B. and Taylor, M. S.: 2004, Trade, growth and the environment, Journal of Economic Literature 42, 7-71.

David, P. A. and Rosenbloom, J. L.: 1990, Marshallian factor market externalities and the dynamics of industrial location, Journal of Urban Economics 28, 349-370.

Döhrn, R.: 2002, Bestimmungsgründe und Auswirkungen von Direktinvestitionen der deutschen chemischen Industrie, RWI-Papiere 79, Rheinisch-Westfälisches Institut für Wirtschaftsforschung, Essen.

Ederington, J., Levinson, A. and Minier, J.: 2005, Footloose and pollution-free, Review of Economics and Statistics 87(1), 92-99. 
Elliot, R. J. R. and Shimamoto, K.: 2008, Are ASEAN countries havens for Japanese pollution-intensive industry?, World Economy 31(2), 236-254.

Eskeland, G. S. and Harrison, A. E.: 2003, Moving to greener pastures? Multinationals and the pollution haven hypothesis, Journal of Development Economics 70, 1-23.

FAO: 2007, ForesSTAT, online database, Food and Agricultural Organization, Rome. available online at http://faostat.fao.org/site/381/default.aspx.

Glaeser, E.: 1999, Learning in cities, Journal of Urban Economics 46, 254-277.

Goldstein, G. and Gronberg, T.: 1984, Economies of scope and economies of agglomeration, Journal of Urban Economics 16, 91-104.

Grether, J. M. and de Melo, J.: 2004, Globalization and dirty industries: Do pollution havens matter?, in R. E. Baldwin and L. A. Winters (eds), Challenges to Globalization: Analyzing the Economics, University of Chicago Press, Chicago, IL.

Hanna, R.: 2004, U.S. environmental regulation and FDI: Evidence from a panel of U.S. based multinational firms, Job market paper, Massachusetts Institute of Technology, Cambridge, MA.

Hausman, J. A. and Taylor, W. E.: 1981, Panel data and unobservable indicidual effects, Econometrica 49, 1377-1398.

Head, K. and Mayer, T.: 2004, Market potential and the location of Japanese investment in the European Union, Review of Economics and Statistics 86(4), 959-972.

Head, K., Ries, J. and Swenson, D.: 1995, Agglomeration benefits and location choice: Evidence from Japanese manufacturing investments in the United States, Journal of International Economics 38, 223-247. 
Hilber, C. A. L. and Voicu, I.: 2006, Agglomeration economies and the location of foreign direct investment: Empirical evidence from Romania, Mimeo, London School of Economics, London, UK.

Jaffe, A. B., Peterson, S. R., Portney, P. R. and Stavins, R. N.: 1995, Environmental regulation and the competitiveness of U.S. manufacturing: What does the evidence tell us?, Journal of Economic Literature 33, 132-163.

Jeppesen, T., List, J. A. and Folmer, H.: 2002, Environmental regulations and new plant location decisions: Evidence from a meta-analysis, Journal of Regional Science 42(1), 1949.

Jorgenson, D. W.: 1966, Rational distributed lag functions, Econometrica 34(1), 135-49.

Kellenberg, D. K.: 2008, An empirical investigation of the pollution haven effect with strategic environmental and trade policy, Mimeo, Department of Economics, University of Montana.

Keller, W. and Levinson, A.: 2002, Pollution abatement costs and foreign direct investment inflows to U.S. states, Review of Economics and Statistics 84(4), 691-703.

Kirkpatrick, C. and Shimamoto, K.: 2007, The effect of environmental regulation on the locational choice of Japanese foreign direct investment, Applied Economics forthcoming.

Krugman, P.: 1991, Geography and Trade, MIT Press, Cambridge, MA.

Levinson, A. and Taylor, S. M.: 2008, Unmasking the pollution haven effect, International Economic Review 49(1).

List, J. A. and Co, C. Y.: 2000, The effects of environmental regulations on foreign direct investment, Journal of Environmental Economics and Mananagement 40(1), 1-20. 
Markusen, J. R.: 1995, The boundaries of multinational enterprises and the theory of international trade, Journal of Economic Perspectives 9(2), 169-189.

Marshall, A.: 1898, Principles of Economics, Macmillan, London, UK.

Millimet, D. L. and List, J. A.: 2004, The case of the missing pollution haven hypothesis, Journal of Regulatory Economics 26(3), 239-262.

Scholz, C. M. and Stähler, F.: 1999, Unilateral Environmental Policy and International Competitiveness, Vol. 299 of Kieler Studien, Mohr Siebeck, Tübingen.

Smarzynska Javorcik, B. K. and Wei, S.-J.: 2004, Pollution havens and foreign direct investment: Dirty secret or popular myth?, Contributions to Economic Analysis 8 Policy 3(2), Article 8 .

van Soest, D. P., List, J. A. and Jeppesen, T.: 2006, Shadow prices, environmental stringency, and international competitiveness, European Economic Review 50, 1151-1167.

Wagner, U. J.: 2001, The design of stable international environmental agreements: Economic theory and political economy, Journal of Economic Surveys 15(3), 377-411.

Wheeler, D. and Mody, A.: 1992, International investment location decisions - the case of U.S. firms, Journal of International Economics 33, 57-76.

World Bank: 2007, World development indicators online, available online. http://devdata.worldbank.org/dataonline/.

World Economic Forum, Cornelius, P. and Schwab, K.: 2003, The Global Competitiveness Report 2002-2003, Oxford University Press, Cambridge, MA. 
World Economic Forum, Porter, M. E., Schwab, K., i Martin, X. S. and Lopez-Carlos, A.: 2004, The Global Competitiveness Report 2003-2004, Oxford University Press, Cambridge, MA.

Xing, Y. and Kolstad, C. D.: 2002, Do lax environmental regulations attract foreign investment?, Environmental and Resource Economics 21(1), 1-22.

Zeng, D.-Z. and Zhao, L.: 2006, Pollution havens and industrial agglomeration, Mimeo, Kagawa University and Kobe University.

\section{Data Appendix}

\section{Foreign Direct Investment}

Reported in thousands of current Euros (numbers from years prior to 1999 were converted at the fixed conversion rate of 1.95 Deutschmark per Euro). German enterprises and households are required by law to report all direct (primary) and indirect (secondary) holdings of 10\% or more of the capital shares or voting rights in an enterprise abroad which has a balance sheet total of more than (the equivalent of) $€ 3$ million and all branch offices or permanent establishments abroad with operating assets in excess of $€ 3$ million to the Deutsche Bundesbank. Based on this information, the Bundesbank calculates annual foreign direct investment flows net of depreciation by destination country and industry. Our sample comprises flow data for the period from 1995 to 2003, covering all 163 host countries available in the Bundesbank database, for 24 industries at the 2 digit level of the WZ93 classification code.

From this sample, we drop all observations from 1995 due to very incomplete reporting, and we exclude Netherlands Antilles, Bahamas and Cayman Islands because they receive predominantly financial investment. For many industries, data are very scarce so we confine the analysis to 6 industries for which comprehensive data are available throughout the 
sample period. The industries and respective WZ93 codes are 21 - Manufacture of pulp, paper and paper products ("paper"), 24 - Manufacture of chemicals and chemical products ("chemicals"), 27 - Manufacture of basic metals ("primary metals"), 29 - Manufacture of machinery and equipment n.e.c. ("machinery"), 31 - Manufacture of electrical machinery and apparatus n.e.c. ("electrical equipment"), and 34 - Manufacture of motor vehicles, trailers and semi-trailers ("automobile").

In some industries we have to deal with large outliers related to major mergers and acquisitions. For example, the merger of Daimler and Chrysler in 1998 generated an FDI flow that exceeded the mean in other years by 17 standard deviations. Neither are such activities the focus of this study nor do they happen frequently, but unfortunately they prove to be highly influential in our linear regression model. To address this problem, we drop the US in the regressions for the automobile industry, the UK for machinery and France for the chemical industry.

\section{Explanatory variables}

EXRATE Time series data on the value of the national currency expressed in US\$ were obtained from the International Financial Statistics (available online at http://www.imfstatistics.org/imf and converted into 10,000 units of national currency per one Euro.

FDISTOCK The annual accumulated stock of total inward FDI is taken from the UNCTAD World Investment Report (available online at http://www.unctad.org/wir). The FDI stock is the value of the share of capital and reserves (including retained profits) attributable to the parent enterprise, plus the net indebtedness of affiliates to the parent enterprise. It is reported in millions of U.S. dollars and converted into Euros using annual average exchange rates. 
GDP Gross domestic product at current market prices in billions of US\$ as reported in the Economist Intelligence Unit (EUI) country data base. The numbers were converted either directly into Euros or into Deutschmark and then into Euros using annual average exchange rates taken from the International Financial Statistics.

LAW \&ORDER Composite risk index on a scale from 1 (very high) to 6 (very low). The "law" sub-component assesses the strength and impartiality of the legal system, and the "order" sub-component assesses popular observance of the law. Monthly observations were obtained from http://www.prsgroup.com and averaged over the period from January 2001 to December 2003.

LITERACY We use the adult literacy rate (age 15 and above) in 1999, reported in percent of total adult population in the Human Development Report 2001 (HDR) published by the United Nations Development Program http://www.undp.org/hdr2001/indicator. Literacy rates for Taiwan were obtained from http://www.asiasource.org.

$\ln$ (AREA) Natural logarithm of the total area in square kilometers taken from World Bank (2007).

$\ln$ (DISTANCE) Natural logarithm of distance between the host country's capital and the city of Frankfurt (Main) measured in kilometers as the crow flies. Frankfurt hosts Germany's financial industry and has the countries largest airport in terms of both passenger and freight traffic volume. Distance was calculated using city coordinates taken from the CIA world factbook (available online at https://www.cia.gov/library/publications/the-world-factbook/).

$\ln ($ ROADS ) Natural logarithm of the total roads network in kilometers. Data were obtained from World Bank (2007) and averaged over the years 2001-03. For a few countries (Hungary, Latvia, Lithuania, Nigeria, and Uruguay), observations from earlier 
years had to be used for lack of recent data.

Pollution abatement cost data are collected by the German Federal Bureau of Statistics (Statistisches Bundesamt) which reports investment in abatement technology as well as current expenditure on abatement by 2-digit WZ93 code industry in its "Fachserie 19, Umwelt, Reihe 3.1 Laufende Aufwendungen für den Umweltschutz im Produzierenden Gewerbe" and "Fachserie 19, Umwelt, Reihe 3.2 Investitionen fr den Umweltschutz im Produzierenden Gewerbe", respectively.

STRINGENCY Stringency of environmental regulation is taken from the Executive Opinion Survey conducted by the World Economic Forum and published in several volumes of the Global Competitiveness Report World Economic Forum et al. (2003). Survey participants have to rank their country with respect to the overall stringency of environmental regulation on a scale between 1 (lax compared with other countries) and 7 (among the world's most stringent). The Executive Opinion Survey is conducted annually, with respondent numbers increasing every year (just over 8,000 as of 2004). It captures the perceptions of leading decision-makers in the business world, many of whom represent the Forum's member companies. The results of the Survey are integral to assessing the competitiveness of a country for the purposes of The Global Competitiveness Report.

TARIFF Unweighted averages for all goods in ad valorem rates, or applied rates, or MFN rates whichever data are available for a longer period, compiled from various sources by the World Bank.

TAX Maximal corporate income tax rates are reported as percentage rates gathered from various volumes of the Index of Economic Freedom published by the Heritage Foundation and the Wallstreet Journal (available online at http://www.heritage.org/index/). 
Whenever this publication reports diverging tax rates for foreign and domestic companies, we take the ones that apply to foreign firms. 
Figure 1: The share of pollution abatement investment in total investment

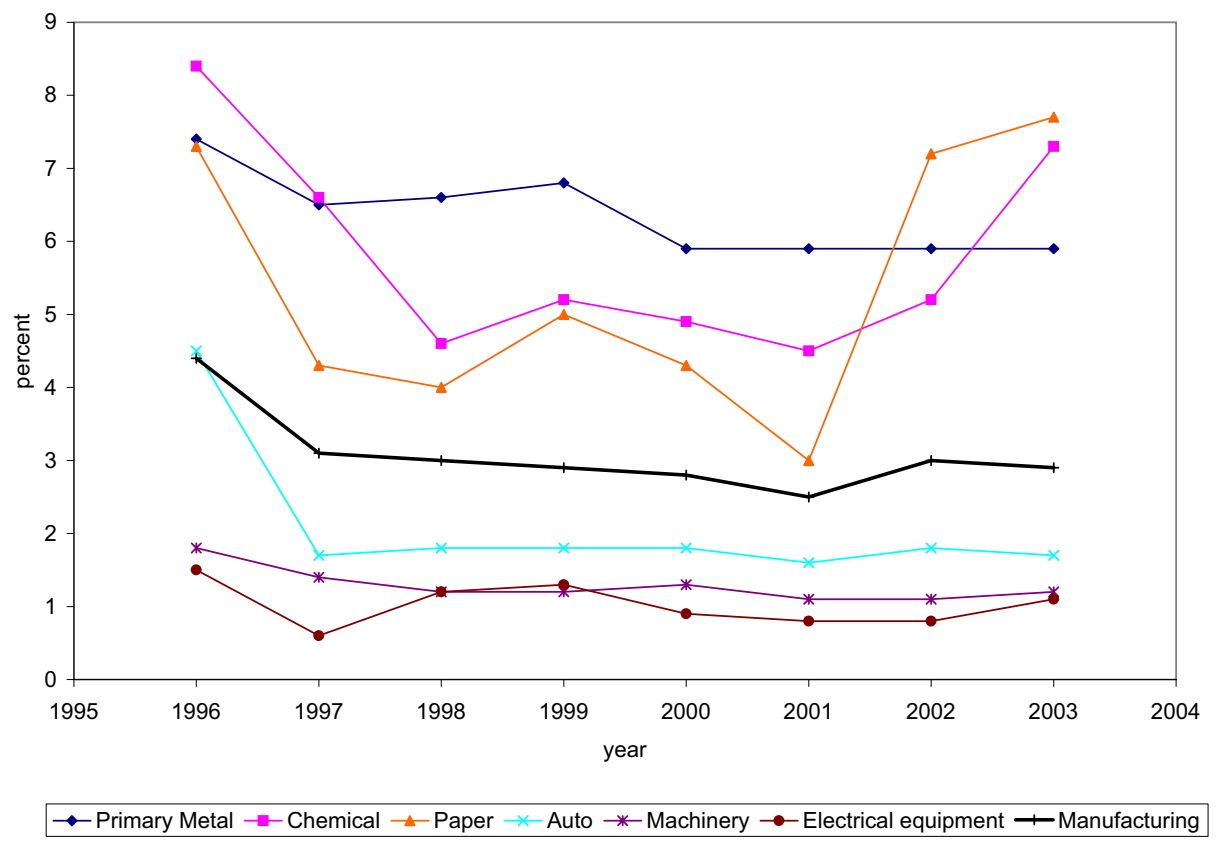

Source: Statistisches Bundesamt

Table 1: Descriptive statistics of time-varying variables

\begin{tabular}{|c|c|c|c|c|c|c|c|c|}
\hline FDI [thousands of $€$ ] & mean & sd, overall & sd, between & sd, within & $\min$ & $\max$ & countries & $N$ \\
\hline Primary Metals & -3.044 & 66.182 & 35.739 & 55.107 & -587 & 174 & 48 & 135 \\
\hline Chemicals & -8.834 & 184.909 & 85.865 & 161.787 & -1789 & 1132 & 99 & 271 \\
\hline Paper & 1.063 & 54.760 & 30.987 & 44.627 & -338 & 529 & 51 & 144 \\
\hline Automobiles & -11.224 & 421.551 & 180.685 & 375.415 & -4186 & 2529 & 81 & 214 \\
\hline Machinery & 0.019 & 117.167 & 56.403 & 100.742 & -1392 & 912 & 97 & 257 \\
\hline Electrical Equipment & -9.056 & 688.791 & 113.88 & 678.778 & -6512 & 4737 & 95 & 268 \\
\hline All Manufacturing & 7.845 & 957.879 & 419.722 & 852.739 & -10518 & 6135 & 135 & 373 \\
\hline STRINGENCY [1-7] & 4.130 & 1.275 & 1.264 & 0.214 & 1.6 & 6.7 & 95 & 245 \\
\hline FDISTOCK [millions of $€$ ] & 505.184 & 1546.204 & 1497.983 & 113.961 & -52.050 & 15966.55 & 144 & 403 \\
\hline TAX [\% rate $]$ & 30.331 & 8.358 & 7.948 & 2.784 & 0 & 55 & 137 & 382 \\
\hline EXRATE $[10,000$ per $€]$ & 1.167 & 12.278 & 11.738 & 2.112 & 0.000 & 169.401 & 143 & 402 \\
\hline TARIFF [\% rate] & 9.53 & 8.570 & 8.067 & 3.188 & 0 & 50.7 & 134 & 379 \\
\hline GDP [billions of $€$ ] & 244.506 & 1039.197 & 1013.44 & 70.264 & 0.649 & 11312.92 & 135 & 384 \\
\hline
\end{tabular}


Table 2: Descriptive statistics of time-constant variables

\begin{tabular}{lrrrrr}
\hline & mean & $\mathrm{sd}$ & $\min$ & $\max$ & $\mathrm{N}$ \\
STRINGENCY in 2003 [1-7] & 4.153 & 1.200 & 2.2 & 6.5 & 77 \\
FDISTOCK average [millions of $€$ ] & 815.018 & 1945.241 & 9.650 & 14832.17 & 77 \\
LITERACY [\% rate] & 88.960 & 14.083 & 40.8 & 99.8 & 77 \\
LAW\&ORDER & 3.975 & 1.457 & 1 & 6 & 77 \\
$\ln ($ ROADS) & 11.542 & 1.476 & 7.567 & 15.670 & 77 \\
$\ln ($ AREA) & 12.391 & 1.934 & 6.515 & 16.612 & 77 \\
$\log ($ DISTANCE) & 8.174 & 1.114 & 5.746 & 9.829 & 77 \\
\hline
\end{tabular}

Table 3: First-stage regression results

\begin{tabular}{|c|c|c|c|c|c|c|}
\hline & $\begin{array}{l}\text { (1) } \\
\text { Primary } \\
\text { Metals }\end{array}$ & $\begin{array}{c}(2) \\
\text { Chemicals }\end{array}$ & $\begin{array}{c}(3) \\
\text { Paper }\end{array}$ & $\begin{array}{c}(4) \\
\text { Automobiles }\end{array}$ & $\begin{array}{c}(5) \\
\text { Machinery }\end{array}$ & $\begin{array}{c}(6) \\
\text { Electrical } \\
\text { Equipment }\end{array}$ \\
\hline $\mathrm{FDI}_{t-1}$ & & & & $\begin{array}{c}-0.399 \\
(0.227)^{*}\end{array}$ & & $\begin{array}{l}-0.224 \\
(0.048)^{* *}\end{array}$ \\
\hline GDP & $\begin{array}{c}0.016 \\
(0.035)\end{array}$ & $\begin{array}{l}-0.636 \\
(0.146)^{* *}\end{array}$ & $\begin{array}{c}0.021 \\
*(0.007)^{* *}\end{array}$ & $\begin{array}{l}1.550 \\
(0.173)^{* *}\end{array}$ & $\begin{array}{l}0.283 \\
(0.080)^{* *}\end{array}$ & $\begin{array}{r}-0.658 \\
(0.893)\end{array}$ \\
\hline TAX & $\begin{array}{c}5.163 \\
(9.436)\end{array}$ & $\begin{array}{c}10.661 \\
(20.359)\end{array}$ & $\begin{array}{c}1.611 \\
(1.978)\end{array}$ & $\begin{array}{c}31.179 \\
(17.017)^{*}\end{array}$ & $\begin{array}{c}-1.097 \\
(2.330)\end{array}$ & $\begin{array}{l}-4.843 \\
(18.953)\end{array}$ \\
\hline EXRATE & $\begin{array}{r}-0.021 \\
(0.283)\end{array}$ & $\begin{array}{c}0.693 \\
(0.590)\end{array}$ & $\begin{array}{c}-0.071 \\
(0.121)\end{array}$ & $\begin{array}{r}-1.120 \\
(0.743)\end{array}$ & $\begin{array}{r}-0.227 \\
(0.138)\end{array}$ & $\begin{array}{r}-0.188 \\
(1.521)\end{array}$ \\
\hline TARIFF & $\begin{array}{c}0.121 \\
(3.925)\end{array}$ & $\begin{array}{c}-28.186 \\
(20.783)\end{array}$ & $\begin{array}{c}0.504 \\
(1.395)\end{array}$ & $\begin{array}{c}-18.675 \\
(17.060)\end{array}$ & $\begin{array}{c}1.581 \\
(5.135)\end{array}$ & $\begin{array}{c}6.091 \\
(16.502)\end{array}$ \\
\hline Observations & 132 & 246 & 138 & 187 & 241 & 258 \\
\hline Countries & 46 & 90 & 49 & 64 & 86 & 88 \\
\hline z statistic $\operatorname{AR}(2)$ & 0.57 & -0.24 & -1.15 & -1.72 & 0.99 & 0.27 \\
\hline Sargan statistic & 13.94 & 27.62 & 14.07 & 23.82 & 19.18 & 32.69 \\
\hline Sargan p-value & 0.83 & 0.12 & 0.83 & 0.53 & 0.51 & 0.14 \\
\hline
\end{tabular}

GMM estimation using twice-lagged levels of endogenous variables as instruments. All regressions include year dummies. Robust standard errors are in parentheses. ${ }^{*}$ significant at $10 \%{ }^{* *}$ significant at $5 \%$. 


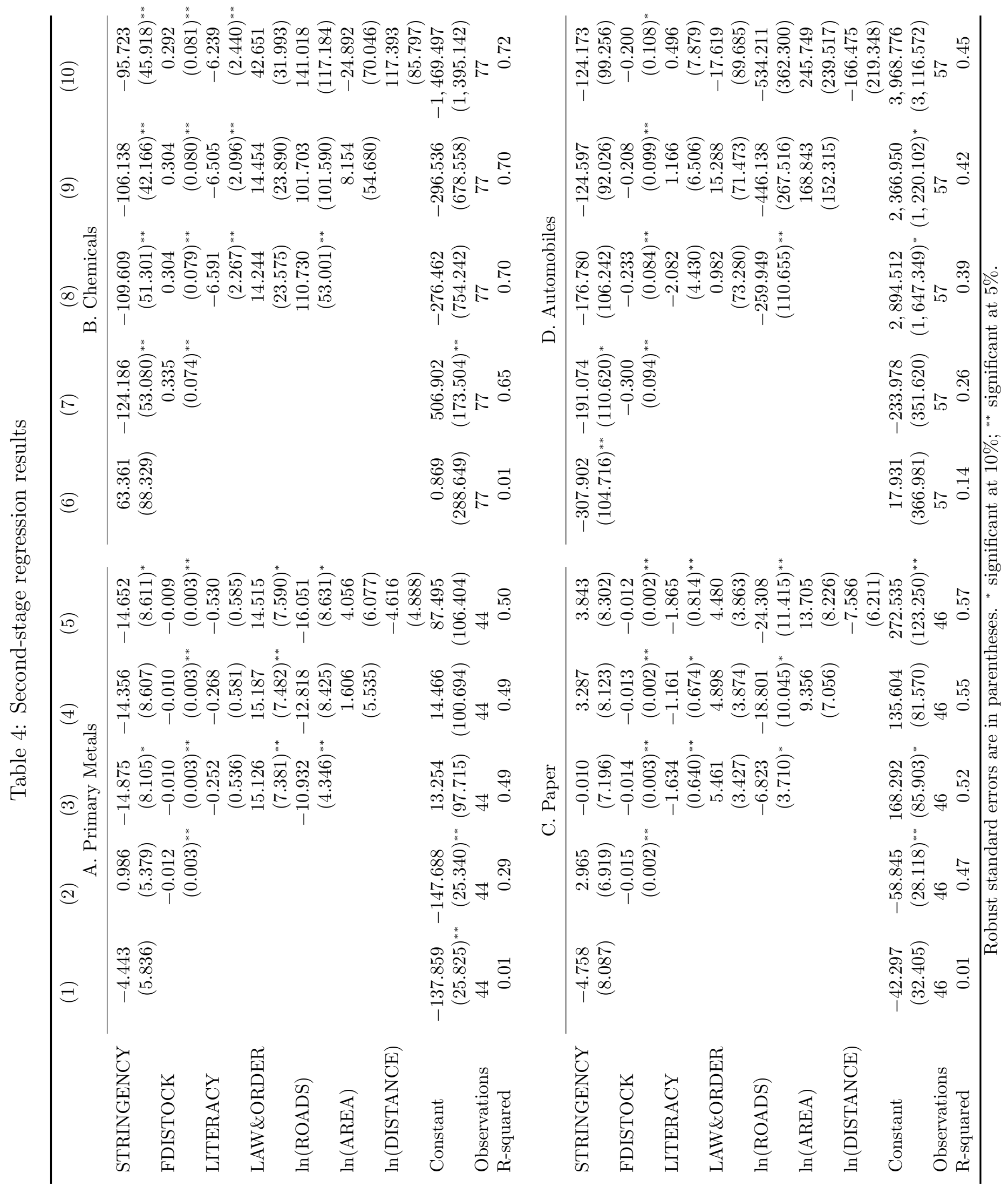




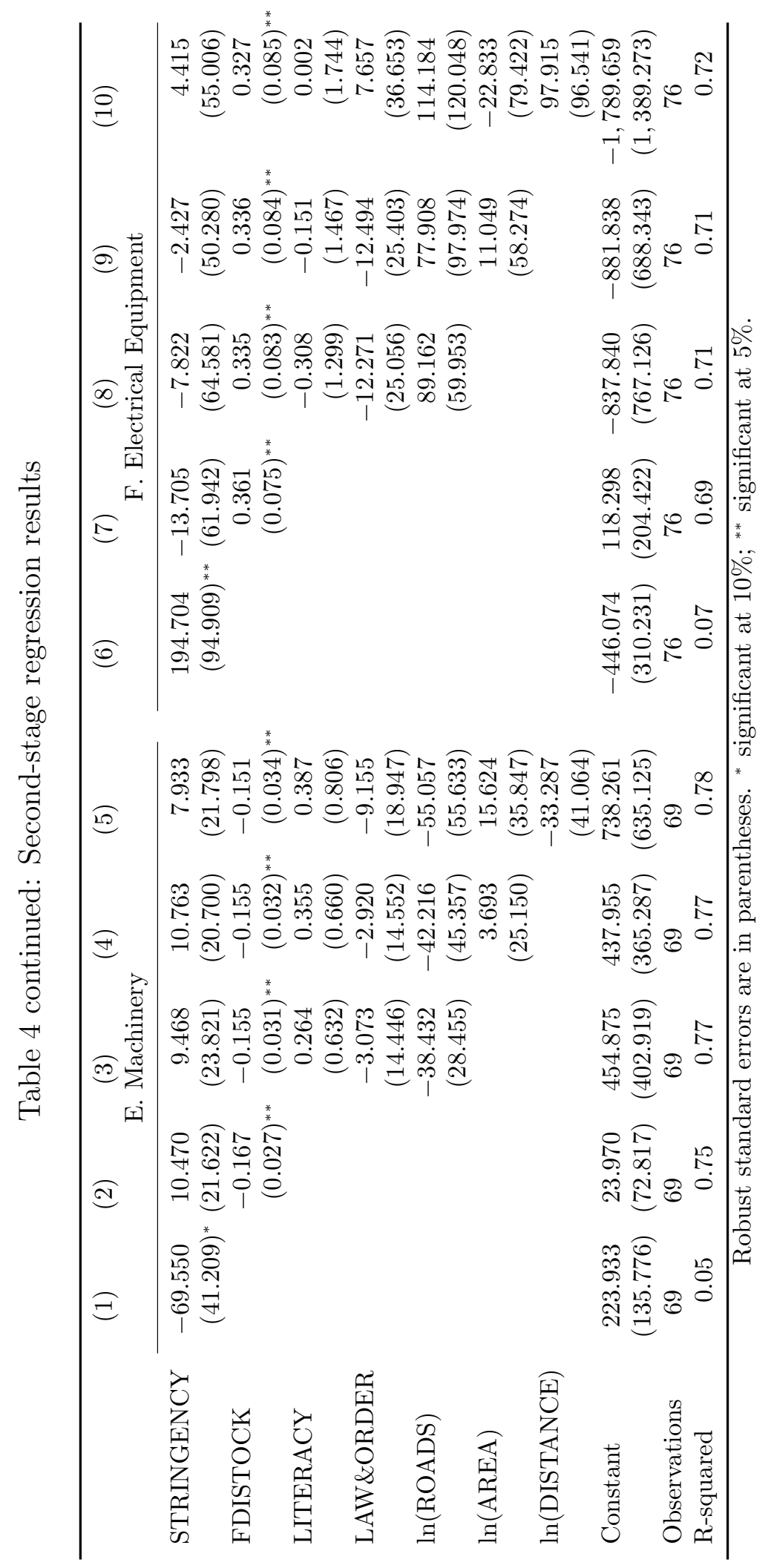




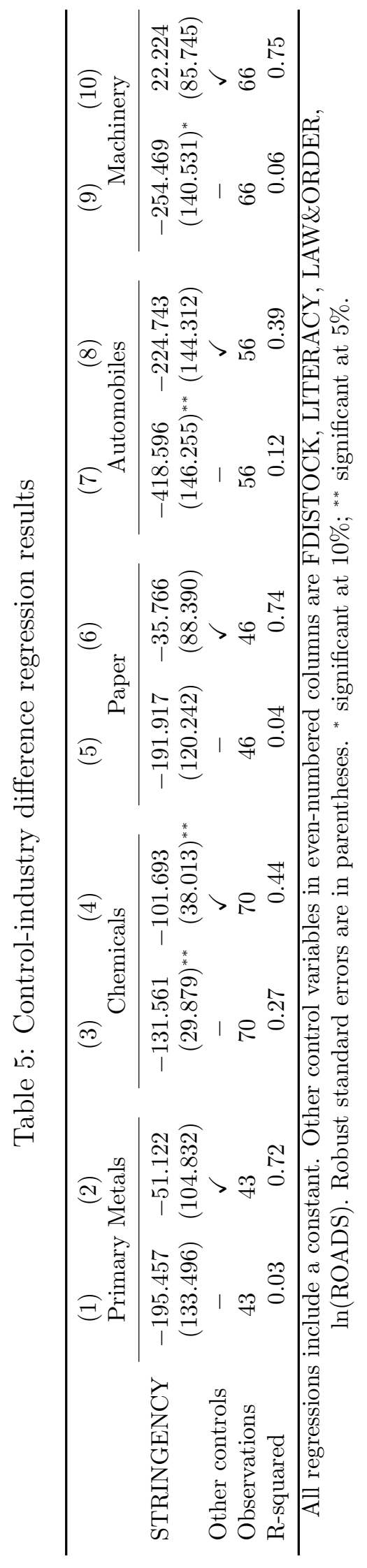

